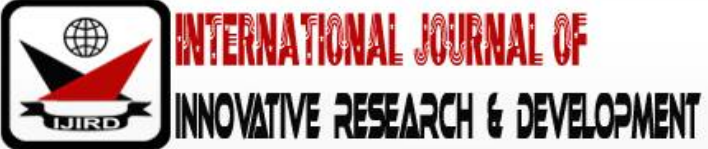

ISSN 2278 - 0211 (Online)

\section{Exchange Rate Volatility and Output Growth in the Economic Community of West African States (ECOWAS) (1980-2015)}

\author{
Dr. Abel Ariyo Awe \\ Professor, Department of Economics, Ekiti State University, Nigeria \\ Dr. Sunday Shina Olalere \\ Lecturer, Department of Economics, Ekiti State University, Nigeria
}

\begin{abstract}
:
This study examined the impact of exchange rate volatility on output growth in the ECOWAS, using time series data spanning from 1980 to 2015. The study employed panel data analysis to examine the relationship between exchange rate volatility and output growth among the selected countries within the ECOWAS countries. GARCH was used to establish the existence of volatility while Panel ARDL was used to assess the magnitude of the effects of exchange rate volatility on output growth in ECOWAS. The result of volatility test from GARCH confirmed the presence of volatility in Real Effective Exchange Rate (REER) across all the selected countries in ECOWAS. Furthermore, the short run ADRL results revealed that, there is a negative but insignificant relationship between exchange rate volatility and output growth in ECOWAS while the long-run ARDL results showed that, exchange rate volatility has positive but insignificant impact on output growth in ECOWAS. Based on the findings of this study, it is therefore recommended that exchange rate policy that will pave way for competitiveness should be formulated by monetary authorities in ECOWSA. In addition, ECOWAS countries should endeavour to add more value to their products before exporting them to other countries.
\end{abstract}

Kevwords: Exchange rate, volatility, output growth and ECOWAS

\section{Introduction}

Over the years, the issues of exchange rate volatility and macroeconomic performance has continued to occupy the front banner in macroeconomic researches all over the world. Different methods have been employed by various researchers and scholars both in developed and developing economies to unravel the impact of exchange rate volatility on output growth such as (Dincer \& Kandil, 2011; Erdal, Erdal \& Esengu, 2012; Alagidede\& Ibrahim, 2016 and Danladi \& Uba, 2016). In Africa, several measures have been taken by various governments in some ECOWAS member countries in order to ensure increase in output of goods and services; one of such measures is to adopt a floating exchange rate thereby devalue their currency. The aim of this is to make their products cheaper at international market and promote output growth. However, after some of the ECOWAS countries adopted floating exchange rate regime, the nominal exchange rate became more volatile (Suranovic, 2005).

Also, in Ghana, the Ghanaian cedi depreciates from GHC0.0036 to US dollar in 1984 to GHC0.0054 to US dollar in 1985 representing 33.3 per cent while growth in real GDP falls from about 8.7 per cent to about 5.1 per cent during this period. In year 2010, the value of Ghana cedi further depreciates from about GHC43 to US dollar in 2010 to about GHC1.51 to US dollar in 2011 representing about 5.4 per cent while growth in real GDP in Ghana almost doubled when it moves from about 7.9 per cent to about 14.05 per cent during this period. More so in Francophone countries, the value of West African CFA Franc Burkina Faso, the West African CFA Franc depreciates from about CFA271.73 to US dollar in 1981 to about CFA328.61 to US dollars in 1982 representing about 20.93 per cent while real GDP in Burkina Faso grew from about 4.55 per cent to about 9.56 per cent during this period (WDI, 2016).

The statistical analyses above show that, devaluation of exchange rate may not necessary lead to output growth. For instance, from the above analysis, it shows that even during the period of appreciation in the exchange rate, some economies record appreciable increase in their level of output growth while some economies record decline in growth level of output in their countries during the period of depreciation in exchange rate. The changes in growth of output in these countries might be as a result of volatility in exchange rate. Hence, in order to ascertain the real impact of exchange rate volatility on output growth, this study examines the relationship between exchange rate volatility and output growth in ECOWAS countries. Several empirical studies have evaluated the impact of exchange rate volatility on output growth in both developed and developing countries. Some of these studies were country specific studies (Sorsa, 1999; Arize, Osangi \& Slotlye, 2000; Dincer \& Kandil, 2011; Erldal et al., 2012; Rasaq, 2013; Otuori, 2013; Akinlo\& Lawal, 2015; Alagidede \& Ibrahim, (2016) \&Ismaila, 2016 etc.). For instance, Dincer\& Rault, (2011) using Vector Autoregressive concluded that, exchange rate policy has significant impact on export growth in Turkey. On his own part, Alagidede et al., (2016) employed GARCH and GMM submitted that, real exchange rate volatility has long-run significant negative impact on 
economic growth in Ghana. Again, Musyoki et al., (2012) using GARCH and GMM found that real exchange rate volatility has negative impact on economic growth in Kenya. However, Munthanhi et al., (2010) using Co-integration concluded that devaluation of the REER has insignificant positive relationship with economic growth in Malawi. Also, Rasaq, (2013) employed OLS and granger causality submitted that exchange rate volatility has positive relationship with economic growth in Nigeria.

While some cross-country studies (Ndlela \& Ndlela, 2002; Danladi, 2012; Caglayan, Dahi \& Demir, 2013; HuchetBourdon \& Mahmani-Oskooee, 2013 etc.). Danladi et al., (2016) using GARCH found that, exchange rate volatility has significant negative impact on economic growth in Nigeria and Ghana. Also, Arize et al., (2002) employed Johansen multivariate method and ECM concluded that exchange rate volatility has negative impact on export flow in 13 less developed countries. On the contrary, Sani, Hassan \& Azam, (2016) using co-integration and ECM submitted that, exchange rate volatility has significant positive relationship with output growth in visually all the Anglophone countries except Liberia. These might have accounted for the controversies in their findings and made the submissions on the impact of exchange rate volatility on output growth to remain inconclusive. As some of the studies argued that exchange rate volatility has negative impact on output growth while other submitted that, exchange rate volatility has positive impact on output growth.

From the studies reviewed above, it could be concluded that most of the reviewed studies are confronted with many controversies and inconclusiveness. This is because most of the empirical studies do not clearly indicate the type of relationship (whether positive or negative relationship) that may actually exist between these variables while some of these studies make use of the same data from both ECOWAS and non-ECOWAS countries in their studies. More so, most of the countries in ECOWAS sub-region were not colonized by the same colonial masters coupled with peculiarities of each country, these might have accounted for different exchange rate policies adopted by most of these countries which many of the reviewed studies failed to take into account in their studies. Therefore, this study accommodates these deficiencies by considering some of the ECOWAS Countries. Finally, these divergent opinions in the reviewed works might also be due to omission of some important variables in establishing the fundamental relationship that may exist between exchange rate volatility and output growth. In order to overcome the limitations of the past works in this regard, this study incorporates export, international interest rate, rate of inflation, Real Effective Exchange Rate as well as exchange rate volatility into Panel ARDL to determine the response of economic growth to exchange rate volatility in ECOWAS countries both in the short-run and long-run.

This study covers the period between 1980 and 2015, which represents the pre-SAP and post-SAP eras. The length of the period allows the study to examine and establish the long run relationship that exists between exchange rate volatility and output growth in ECOWAS countries. Precisely, the chosen period is long enough to meet the minimum observation requirement necessary for the Panel ARDL estimation technique is employed in this study. The study focuses on exchange rate volatility and output growth in ECOWAS countries simply because cross countries research coverage of this type presents an in-depth research work on exchange rate volatility model estimate and its appropriate implementation shall lead to higher economic growth and sustainable development in ECOWAS countries. Although, there are three groups of countries in ECOWAS namely: Anglophone Francophone and Lusophone, however, this study focuses on Anglophone countries. Anglophone countries consist of Nigeria, Ghana, Gambia, Sierra Leone and Liberia. Four countries are selected Anglophone within ECOWAC countries. The selection criteria are Size, Common Monetary Policy, Economic Union, Gross Domestic Product as well as volume of their Exports. Under the Anglophone countries, four countries are selected namely; Nigeria, Ghana, Sierra Leone and Gambia.

\section{Methodology}

This study employed a single equation. The single equation is enough to assist in presenting a robust representation of the impact of exchange rate volatility on output growth in the ECOWAS countries. Following the theoretical proposition of Balassa-Samuelson's approach to the relationship between economic growth and exchange rate which was developed by Balassa (1964) and Samuelson (1964) which was adopted by Harberger (2003), Drineet al., (2004) and Yanping, et al., (2010) in modeling their studies. The model of this study is in linear form and it mirrors the studies mentioned above with little modification.

$R G D P g r_{i t}=f\left(V O L_{i t}, E X P_{i t}, I N F_{i t}, R I N T_{i t}, R E E R_{i t}\right)$

The model for objective of this study is explicitly specified as follow:

$R_{G D P g r}{ }_{i t}=\alpha_{0}+\alpha_{1} V O L_{i t}+\alpha_{2} E X P_{i t}+\alpha_{3} I N F_{i t}+\alpha_{4} R I N T_{i t}+\mu_{i t}$

where RGDPgr is Growth Rate of Real Gross Domestic Product, REER is Real Effective Exchange Rate, VOL is

Exchange Rate Volatility, EXP is Export, INF is Rate of Inflation, RINT is Real Interest Rate, $i$ entity or country, $t$ is

time or year, $u_{[t}$ is error or stochastic terms, $\alpha_{0}$ is constant $t$ value or the intersect $\mathrm{t}, \alpha_{1}, \alpha_{2}, \alpha_{3}, \alpha_{4}$ are the coefficients of the variables.

\subsection{Sources of Data}

The data set for this study consists of annual time series spanning from 1980 to 2015 for the purpose of investigating the impact of exchange rate changes on output performance in the ECOWAS. Data on the growth rate of Real Gross Domestic Product (RGDPgr), Real Effective Exchange Rate (REER), Consumer Price Index as proxy for Inflation (INF), Real International Interest Rate (RINT) as well as percentage of Exports to GDP (EXP) for all the fifteen ECOWAS member countries are sourced from World Development Indicator WDI (2017) while data on Volatility in Exchange Rate is collected from GARCH results. 


\subsubsection{Estimation Techniques}

The estimation techniques employ in this study are GARCH, Panel Auto-regressive Distribution Lag (ARDL). Unit root test is carried out to determine the time series characteristics of the variables in this study. Panel ARDL technique is also employed to examine both the short run and long run relationship between exchange rate volatility and output growth in the ECOWAS.

\section{Results and Discussion of Findings}

\begin{tabular}{|c|c|c|c|c|c|}
\hline Variables & Observations & Mean & Std. Dev. & Minimum & Maximum \\
\hline RGDPgr & 288 & 3.34 & 5.38 & -20.49 & 33.74 \\
\hline REER & 288 & 250.05 & 302.37 & 49.78 & 3660.64 \\
\hline RINT & 288 & 4.89 & 12.66 & -51.62 & 33.47 \\
\hline EXPT & 288 & 28.48 & 12.38 & 3.34 & 59.90 \\
\hline INF & 288 & 13.32 & 21.68 & -35.84 & 178.70 \\
\hline
\end{tabular}

Table 1: Descriptive Statistics of Variables

Source: Author's Computation, 2017

In Table 1 above, the results of the estimated mean value which show the data distribution, recorded the highest mean value of 250.04 for REER (Real Effect Exchange Rate) while RGDPgr (Real Gross Domestic Product Growth Rate) has the lowest mean value of 3.34. One major observation is standard deviation which measures the variability of the data, all the standard deviation values are positive. Variable like REER (302.3720) has higher standard deviation which shows higher variability while other variables like INF (21.68), RINT (12.66), EXPT (12.38) and RGDPgr (5.38) have low standard deviation with low variability.

\subsection{Volatility Test}

Since one of the issues in this study is to check for volatility clustering in the exchange rate, the study starts by checking for Heteroscedasticity in the real effective exchange rate data series. The lag length was selected at 5 . The result of the ARCH LM test is presented in Table 2.

\begin{tabular}{|c|c|c|c|}
\hline F-Statistics & $\mathbf{1 2 . 0 8 0 2 7}$ & Prob.F (5,277) & $\mathbf{0 . 0 0 0 0}$ \\
\hline Obs*R-squared & 50.66247 & Prob. Chi-Square(5) & 0.0000 \\
\hline
\end{tabular}

Table 2: Heteroskedasticity Test: Arch On Reer?

Source: Author's Computation, 2017

Table 2 shows the results of $\mathrm{ARCH}(5)$ test. The probability of F-statistics and $\mathrm{T}^{*} \mathrm{R}^{2}$ are both zero, the null hypothesis of no heteroskedasticity is rejected. This indicates the presence of ARCH (volatility) in REER (Real Effective Exchange Rate) data across the selected countries. With this result, the study then proceeds to test for degree of volatility in the data using the ARCH/ GARCH method. The results of the ARCH/ GARCH are presented in Table 3.

\begin{tabular}{|c|c|c|c|c|}
\hline \multicolumn{5}{|c|}{ Dependent Variable: REER } \\
\hline \multicolumn{5}{|c|}{ Method: ML ARCH - Normal distribution (OPG - BHHH/ Marquardt steps) } \\
\hline \multicolumn{5}{|c|}{ Presample variance: backcast (parameter $=0.7$ ) } \\
\hline \multicolumn{5}{|c|}{ GARCH $=\mathrm{C}(4)+\mathrm{C}(5) * \mathrm{RESID}(-1)^{\wedge} 2+\mathrm{C}(6) * \mathrm{GARCH}(-1)$} \\
\hline Variable & Coefficient & Std. Error & z-Statistic & Prob. \\
\hline $\mathrm{C}$ & 157.8178 & 6.804876 & 23.19187 & 0.0000 \\
\hline $\mathrm{AR}(1)$ & 0.802459 & 0.027607 & 29.06727 & 0.0000 \\
\hline $\mathrm{MA}(1)$ & 0.043139 & 0.067213 & 0.641813 & 0.5210 \\
\hline & $\begin{array}{l}\text { Variance } \\
\text { Equation }\end{array}$ & & & \\
\hline $\mathrm{C}$ & 412.2284 & 67.89457 & 6.071596 & 0.0000 \\
\hline RESID(-1)^2 & 2.643674 & 0.416397 & 6.348932 & 0.0000 \\
\hline GARCH(-1) & 0.029573 & 0.013855 & 2.134517 & 0.0328 \\
\hline R-squared & 0.520562 & Mean dependent var & & 250.049 \\
\hline Adjusted R-squared & 0.517198 & S.D. dependent var & & 302.372 \\
\hline S.E. of regression & 210.1 & Akaike info criterion & & 10.76609 \\
\hline Sum squared resid & 12580476 & Schwarz criterion & & 10.8424 \\
\hline Log likelihood & -1544.32 & Hannan-Quinn criter. & & 10.79667 \\
\hline Durbin-Watson stat & 2.300064 & & & \\
\hline
\end{tabular}


The GARCH ${ }_{t-1}^{2}$ term is the volatility from previous period measures as the lag of the square residual from the mean equation is 2.643674 and the GARCH term ${ }^{2}{ }_{t-1}^{2}$ is the last period forecast variance is 0.029573 in Table 3 . They are both significant at $5 \%$ level.

The rule of thumb for determining the presence of volatility after summing the root of autoregressive model is that:

If $\alpha+\beta$ is less than 0.5 , there is no volatility

If $\alpha+\beta$ is fall between 0.5 and 1 , there is volatility

If $\alpha+\beta$ is greater than 1 , this is a case of overshooting.

The sum of the two coefficients is 2.6732 , which is greater than 1.0. This shows that real effective exchange rate in the ECOWAS is overshooting, that is, high level of volatility is present in real exchange rate. To test the effect of this volatile nature on economic growth in our panel model a new series is generated designated as exchange rate volatility coefficient (VOL).

\subsection{Panel Unit Root Test}

The methods of panel unit root test adopted for this study are Im, Pesaran \& Shin (IPS) and Augmented-Dickey Fuller (ADF) tests. The test has been proven to be suitable in verifying stationarity of variables in panel data Maddala \& Wu, (1999) and Im, Pesaran \& Shin, (2003). For comparison and clarification, the ADF Fisher Unit root test was also used. The results are presented in Table 4.

\begin{tabular}{|c|c|c|c|c|c|c|c|c|c|}
\hline & \multicolumn{4}{|c|}{ At Level } & \multicolumn{3}{c|}{ First Difference } & \\
\hline Variable & IPS & & $\begin{array}{c}\text { ADF- } \\
\text { Fisher } \\
\text { Chi- } \\
\text { Square }\end{array}$ & Prob. & Statistic & Prob. & $\begin{array}{c}\text { ADF - } \\
\text { Fisher } \\
\text { Chi- } \\
\text { square }\end{array}$ & Prob. & \\
\hline REER & -4299 & 0.076 & 22.5473 & 0.126 & -11.5332 & 0.0000 & 169.212 & 0.0000 & $\mathrm{I}(1)$ \\
\hline VOL & -5.11641 & 0.0000 & 63.7542 & 0.0002 & & & & & $\mathrm{I}(0)$ \\
\hline RGDPgr & -12.5035 & 0.0000 & 136.234 & 0.0000 & & & & & $\mathrm{I}(0)$ \\
\hline EXP & -12.7516 & 0.0000 & 158.668 & 0.0000 & & & & & $\mathrm{I}(0)$ \\
\hline RINT & -7.96245 & 0.0000 & 54.4539 & 0.0000 & & & & & $\mathrm{I}(0)$ \\
\hline INF & -8.04025 & 0.0000 & 85.7832 & 0.0000 & & & & & $\mathrm{I}(0)$ \\
\hline
\end{tabular}

Table 4: Panel Unit Root Test

Source: Author's Computation, 2017

The results of panel unit root test as shown in Table 4 examine the statistical prosperities of all the variables. The Im, Peseran \& Shin and ADF- Fisher Chi-square panel unit root test for unit root are conducted for the variables in the model. The null hypothesis tested for the IPS and ADF is $H_{0}: \alpha_{1}=0$ for all countries while the alternative hypothesis is

$H_{1}: \alpha_{1}<0$, for at least one country. The lag lengths are selected using the Akaike Information Criterion. The results of the test at level and first difference are presented accordingly, the null hypothesis is that test is a unit in each series, that is, each variable is non-stationary. The rule of thumb is that, the null hypothesis should be accepted if the IPS and ADF statistics are less negative, meaning that, greater than the critical value at any chosen level of significance. The results of IPS and ADF in Table 4 indicate that all the variables are integrated of order zero, that is, I(0) except REER which found to be integrated of order one, that is, I(1)This should be expected given the volatile nature of the variable. The result of the unit root test thus suggests the use of panel ARDL Cointegration test. However, the generated series from the ARCH/ GARCH test of REER, (VOL) was found to be stationary at level as shown in Table 4. Based on this all variables in the model are stationary at their level, therefore static Panel data regression on the series cannot be spurious.

\subsection{Bound Test for ECOWAS}

The rule of thumb is that, if the computed F-statistics falls below the lower bound value I $(0)$, the null hypothesis is (no cointegration) is accepted. But if the computed F-statistics exceeds the upper bound value I(1), the null hypothesis is rejected thus, there is existence of long-run relationship. If the computed result falls between the lower and upper bounds, then the test is inconclusive. Based on this, the result of Bound test from Table 5 shows that, the null hypothesis of no cointegration is rejected since the F- statistic value of 37.90 is higher than the upper bound critical value of 5.06 (restricted) at $1 \%$ level from Table 6. 


\begin{tabular}{|c|c|c|}
\hline \multicolumn{3}{|c|}{ ARDL Bounds Test } \\
\hline \multicolumn{3}{|c|}{ Included observations: 268 } \\
\hline \multicolumn{3}{|c|}{ Null Hypothesis: No long-run relationships exist } \\
\hline Test Statistic & Value & $\mathrm{K}$ \\
\hline F-statistic & 37.9018 & 4 \\
\hline \multicolumn{3}{|c|}{ Critical Value Bounds } \\
\hline Significance & I0 Bound & I1 Bound \\
\hline $10 \%$ & 2.45 & 3.52 \\
\hline $5 \%$ & 2.86 & 4.01 \\
\hline $2.50 \%$ & 3.25 & 4.49 \\
\hline $1 \%$ & 3.74 & 5.06 \\
\hline
\end{tabular}

Table 5: Bound Test for Cointegration in ECOWAS

Source: Author's Computation, 2017

\begin{tabular}{|c|c|c|c|c|}
\hline \multirow{2}{*}{} & \multicolumn{2}{|c|}{$\mathbf{5 \%}$ Critical Value } & \multicolumn{2}{c|}{ 1\% Critical Values } \\
\cline { 2 - 5 } & Lower & Upper & Lower & Upper \\
\hline Restricted Intercept No trend & 2.27 & 3.28 & 2.88 & 3.99 \\
\hline Unrestricted Intercept No trend & 2.45 & 3.16 & 3.15 & 4.43 \\
\hline
\end{tabular}

Table 6: Bound Test for Cointegration

Source: Pesaran, Et Al, 2001

3.4. Panel ARDL Long-Run and Short-Run Analyses for ECOWAS

\begin{tabular}{|c|c|c|c|c|}
\hline \multicolumn{5}{|c|}{ Dependent Variable: D(RGDPgr) } \\
\hline \multicolumn{5}{|c|}{-Dynamic regressors (4 lags, automatic): VOL RINT INF EXPT } \\
\hline \multicolumn{5}{|c|}{ Selected Model: ARDL(1,1,1,1,1) } \\
\hline Variable & Coefficient & Std. Error & t-Statistics & Prob. \\
\hline \multicolumn{5}{|c|}{ Long Run Equation } \\
\hline VOL & 0.000413 & 0.001295 & 0.318860 & 0.7501 \\
\hline RINT & -0.066545 & 0.040763 & -1.632493 & 0.1039 \\
\hline INF & -0.096001 & 0.024999 & -3.840247 & $0.0002^{* *}$ \\
\hline EXPT & 0.046421 & 0.030538 & 1.520136 & 0.1298 \\
\hline \multicolumn{5}{|c|}{ Short Run Equation } \\
\hline COINTEQ01 & -0.877561 & 0.105026 & -8.355620 & $0.0000^{* * *}$ \\
(ECM) & -0.025058 & 0.018556 & -1.350389 & 0.1782 \\
\hline D(VOL) & 0.157468 & 0.046204 & 3.408135 & $0.0008^{* *}$ \\
\hline D(RINT) & 0.065455 & 0.048048 & 1.362279 & 0.1744 \\
\hline D(INF) & -0.036635 & 0.117246 & -0.312461 & 0.7550 \\
\hline D(EXPT) & 3.331593 & 0.657209 & 5.069303 & $0.0000^{* * *}$ \\
\hline C & Akaike Info Criterion & 5.537692 \\
\hline & Schwarz Criterion & 6.199060 & \\
\hline & Hannan-Quinn Criterion & 5.802728 \\
\hline
\end{tabular}

Table 7: Panel ARDL Long Run and Short Run Results for ECOWAS

Source: Author's Computation, 2017

Note: * Is $10 \%$ Level Significance, ** 5\% Level of Significance and *** Is 1\% Level of Significance

From Table7 above, the long run equation indicates that, real interest rate and inflation exert an inverse relationship with output growth in ECOWAS countries. This implies that a unit increase in the level of real interest rate and inflation rate brings about 6.66 per cent and 10 per cent decrease respectively in the level of output growth in ECOWAS countries. This found to be significant at 5\% level in the case of inflation. This implies that, high price level discourages consumptions thereby leading to reduction in output growth in ECOWAS. This finding is in support of a prior expectation and is in line with the submission of Danladi, (2013) who found that, inflation has a negative impact on output growth in West African Sub-region. However, Exchange rate Volatility and Export growth exhibit direct and insignificant relationship with output growth in ECOWAS countries in the long run. This suggests that, a unit increase in exchange rate volatility will lead to about 0.04 per cent increase in output growth level. More so, a unit increase in export will result in about 4.64 per cent increase in output growth level in ECOWAS sub region in the long run. This finding supports Azeez, Kolapo \& Ajayi, (2012); Rasaq, (2012); Enakwe, Ordu \& Nwoha, (2013) and Huchet-Bourdon et al., (2013) who confirm that, positive relationship exists between exchange rate volatility and economic growth. From the result on the relationship that exists between exchange rate volatility and output growth in ECOWAS countries in the long-run from our findings, it shows that exchange rate volatility does not have any impact on output growth on ECOWAS economies in the long run. This may be as a result of low value tradable goods and services at the world market and adoption of different policies by different countries within ECOWAS sub-region. 
From Table 7 above, short run result indicates the confirmation of co-integration among the variables adopted in the equation and it was significant at 1\%. The first difference of real interest rate (RINT) exhibits a direct relationship with output growth in ECOWAS countries in the short run. This implies that an increase in real international interest rate (RINT) will lead to 15.7 per cent increase in the level of output growth in ECOWAS countries and it is statistically significant at 5\%. This suggests that the high interest rate in each of the ECOWAS country has discouraged the local investors and this has motivated the foreign investors to mobilize their capital for an investment in ECOWAS thereby stimulating output growth within the ECOWAS sub-region This finding negates our a priori expectation. This finding may be as a result of different monetary policies adopted and implemented by different monetary authorities within ECOWAS sub-region. Again, first difference of Inflation (DINF) seems to have a positive relationship with output growth in ECOWAS countries. This suggests that, an increase in changes in the level of inflation leads to about 6.55 per cent increase in output growth within ECOWAS. On the other hand, exchange rate volatility (DVOL) and export growth (DEXP) exert a negative relationship with output growth in ECOWAS countries. This implies that, an increase in changes in exchange rate volatility and export cause output growth to decline by about 2.51 per cent and 3.66 per cent respectively in the short-run. This result is also in-line with the submissions of Musyoki et al., (2012); Alagidede et al., (2016); Danladi et al., (2016) that, exchange rate volatility exerts a negative impact on economic growth. The coefficient of ECM which measures the speed of adjustment back to equilibrium is -0.877561 and it is significant at $1 \%$ level with the negative sign. This indicates that about $88 \%$ of previous disequilibrium is adjusted in the model in the short run within the ECOWAS countries.

\section{Discussion of Findings}

Various econometric tests were conducted in this study. Since volatility in exchange rate is one of the key points in this research work. The study conducts volatility test using GARCH. The result shows the presence of volatility in REER across all the selected countries in ECOWAS. This result is in line with findings Olimov, et al., (2008) who submitted that, there is existence of volatility in the rate of exchange rate. Again, stationary test was conducted first to avoid spurious regression, using Im, Pesaran and Shin (IPS) and Augmented-Dickey Fuller (ADF Fisher). The results revealed that all the series are not integrated of the same order. While RGDPgr, VOL, EXP, RINT, and INF are stationary at their levels, REER is stationary at first difference. The condition for panel co-integration was not met, therefore, the study proceeds to Panel Autoregressive Distributed Lag (ARDL). The panel data analysis was then conducted to analyze the impact of exchange rate volatility on output growth in ECOWAS. The short run ARDL results for ECOWAS show that, first difference of exchange rate volatility and export has negative impact on output growth. This means that, an increase in exchange rate volatility and export lead to a reduction in output growth rate in short run within ECOWAS sub-region. However, first difference in real international interest rate and inflation indicate a positive relationship with output growth. This suggests that, changes in international interest rate and inflation causes an increase in output growth within ECOWAS sub-region in the short run. This implies that, the high rate of interest in each ECOWAS country has encourage the foreign the investors to bring-in their capital and invest it in ECOWAS thereby increase the output level in ECOWAS sub-region.

The long-run analysis from the ARDL results for ECOWAS countries were also carried out. The results show that, exchange rate volatility and export have positive. It implies that, an increase in exchange rate volatility and export cause an increase in output growth rate within ECOWAS sub-region in the long run. The result is in line with Azeez et al., (2012) who submitted that exchange rate volatility has long-run positive impact on economic growth. However, real international interest rate and inflation have negative impact on output growth in ECOWAS. Among these two variables, only impact of inflation was found to be significant in the long run in ECOWAS. This implies that, high price level discourages consumption thereby reduced output growth in ECOWAS in the long run. This result is also in line with result of Danladi (2013) who found that, inflation has a negative impact on output growth in west African sub-region.

\section{Conclusion}

Based on the results and findings of this study, the following conclusions were made: Judging from the analysis of impact of exchange rate volatility on output growth in ECOWAS, the study revealed that exchange rate volatility and export have insignificant negative impact on output growth ECOWAS countries in the short run. However, variables like real international interest rate and inflation showed negative relationship with output growth within the ECOWASregion in the long run. These relationships were significant in case of inflation but found to be insignificant in case of real interest rate in ECOWAS in the long run. We therefore conclude that, increase in exchange rate volatility is not proportionally significant to output growth in ECOWAS. It was therefore concluded that, exchange rate volatility has little or no impact on output growth in ECOWAS. This may be attributed to different monetary policies and lack of proper institutional framework being put-in-place within this sub-region and these in-turn have an impact on the level of investment and output growth in ECOWAS.

\section{Policy Recommendations}

In view of all the aforementioned findings in this research work, the following recommendations are therefore put forward:

- Exchange rate policy that will pave way for competitiveness should be formulated and implemented by the monetary authorities within ECOWAS sub-region.

- ECOWAS countries should endeavour to add more value to their products before exporting them to other countries. 
- Efforts should be made to look at the real sector of ECOWAS economy, such as manufacturing sector in order to broaden ECOWAS countries and diversify their export base.

\section{References}

i. Alagidede, P. \& Ibrahim, M. (2013). On the Causes and Effects of Exchange Rate Volatility on Economic Growth: Evidence from Ghana. International Growth Centre (IGC). Working Paper. 1 - 28.

ii. Akinlo, O. O. \& Lawal, Q. A. (2015). Impact of Exchange Rate on Industrial Production in Nigeria. International Business and Management. Vol. 10. No.1.104-110.

iii. Arize, A. C., Osang, T. \& Slottje, D. (2000). Exchange Rate Volatility and Foreign Trade: Evidence from 13 LDCs. Journal of Business and Economic Statistics, 18(1): 0-17.

iv. Azeez, B. A; Kolapo, F. T and Ajayi, L. B (2012). Effect of Exchange Rate

v. Volatility on Macroeconomic Performance in Nigeria. Interdisciplinary Journal of Contemporary Research in Business. Vol. 4, No.1.149 - 155.

vi. Caglayan, M., Dahi, S. O. \& Demir, F. (2013). Trade Flow Exchange Rate Uncertainties and Financial Depth: Evidence from 28 Emerging Countries. Southern Economic Journal, 79(4): 905-927.

vii. Central Bank of Nigeria (CBN) (2015). Statistical Bulletin. Vol. 20.

viii. Danladi, J. D. (2013). Inflation and Sustainable Output Performance in West African Sub-Region: The Threshold Effect. American Journal of Economics. 3(6) 252-259.

ix. Danladi, J. D. \& Uba, U. P. (2016). Does the Volatility of Exchange Rate Affect the Economic Performance of Countries in the West Africa Monetary Zone? A Case of Nigeria and Ghana. British Journal of Economics, Management and Trade, 11(3): 1-10.

x. Dincer, N. \& Kandil, M. (2011). The Effect of Exchange Rate Fluctuation on Export: Sectorial Analyses for Turkey. The Journal of International Trade \& Economic Development, 20(6): 809-837.

xi. Drine, I. \& Rault, C. (2004). Does the Balassa-Samuelson Hypothesis Hold for Asian Counties? An Empirical Investigation. Applied Econometrics and International Development, 2(4):59-84.

xii. Enekwe, C. I.; Ordu, M. M. \& Nwoha, C. (2013). Effect of Exchange rate Fluctuations on Manufacturing Sector in Nigeria. European Journal of Business and Management. Vol. 5. No 22. Pp 67-73.

xiii. Erdal, G., Erdal, H. \& Esengu, K. (2012). The Effect of Exchange Rate Volatility on Trade: Evidence from Turkey Agricultural Trade. Applied Economics Letters, 19: 297-303.

xiv. Harberger, A. C. (2003). Economic Growth and the Real Exchange Rate: Revisiting the Balassa-Samuelson Effect. Paper Prepared form Conference of Organized by the Higher School of Economics, Moscow. 1-28

xv. Huchet-Burdeon, M. \& Mahamanm-Oskoee, B. (2013). Exchange Rate Uncertainty and Trade Flows between the United States and China: The agricultural versus the non-agricultural sector. The Chinese Economy, 46(2): 29-53.

xvi. Im, K. S., Pesaran, M. H. \& Shin, Y. (2003). Testing for Unit Root in Heterogeneous Panels. Journal of Econometrics, 115: 53-74.

xvii. International Monetary Fund (IMF) (2010). The Federal Domestic Republic of Ethiopia: Second Review of the Arrangement under Exogenous Shock Facility.

xviii. Ismaila, M. (2016). Exchange Rate Depreciation and Nigeria Economic Performance after Structural Adjustment Programmes (SAP). NG-Journal of Social Development. Vol, 5. No 2. 122-132.

xix. Maddala, G. S. \& Wu, S. (1999). A Comparative Study of Unit Root Tests with Panel Data and a New Sample Test. Oxford Bulletin of Economics and Statistics, 61: 631-652.

xx. Munthali, T., Simwale, K. \& Nwale, M. (2010). The Real Exchange Rate and Growth in Malawi: Exploring the Transmission Route. Journal of Development and Agricultural Economics, 2(9): 303-315. Available online at www.academicjournal.org.

xxi. Ndlela, D.B \&Ndlela, T. (2002), Exchange Rate Policy and Trade Facilitation in Regional Integration Agreement. The Case of Southern African Economies. Trade and International Policy Strategies, Annual Forum. Muldersdrift.

xxii. Olayunbo, D; Yinusa, O. \& Akinlo, A. (2011). Effects of Exchange Rate Volatility on Trade in Some Selected SubSaharan African Countries. Scientific Research, Modern Economy, 2, Pp 538-545.

xxiii. Olimov, U. \& Sirajiddinov, N. (2008). The Effect of the Real Exchange Volatility and Misalignment on Foreign Trade Flows in Uzbekistan. Economics Discussion Paper.

xxiv. Otuori, O. H. (2013). Influence of Exchange Rate Determinants on the Performance of Commercial Banks in Kenya. European Journal of Management Sciences and Economics, 1(2), 86-98.

xxv. Rasaq, A. D. (2013). The Impact of Exchange Rate Volatility on the Macroeconomics Variables in Nigeria. European Scientific Journal, 9(7): 152-165.

xxvi. Sani, I. A; Hassan, S. \& Azam, M. (2016). Effects of Exchange Rate Volatility on Outputs in Some Selected West African Countries. International Journal of Development and Economic Sustainability, 4(1): 1-10.

xxvii. Sorsa, P. (1999). Algeria: The Real Exchange Rate, Export Diversification and Trade Protection. Policy Development and Review Department International Monetary Fund.

xxviii. Suranovic, S. M. (2005). International Finance: Theory and Policy. 75-78.

xxix. World Development Indicator (WDI), (2016).

xxx. Yanping, C; Oscar, J. \& Alan, M. T. (2010). The Harrod-Balassa-Samuelson Hypothesis: Real Exchange Rate and their Long-Run Equilibrium. National Bureau of Economic Research, 1-29 